\title{
Sustainability in the Tourism Business
}

\author{
Massimo Battaglia*
}

\begin{abstract}
Sustainable tourism is a multi-stakeholder issue, whose aim is to stimulate the balanced exploitation of natural resources at the local level and to limit the social and environmental impacts. The businesses operating in the tourism sector mainly consist of SMEs. Their impact, although less significant if considered individually, are significant at the local level, particularly considering the cumulative effects produced by tourism businesses in a specific area and the role such businesses can play in influencing the behavior of tourists/guests. Focusing on the positive impacts and limiting the negative effects at social and environmental levels, represent the key to sustainable tourism for businesses.
\end{abstract}

Keywords: Sustainability; Global Tourism; SME; Sustainable Tourist; Sustainability Certifications

\section{Sustainable Tourism}

Although the notion of sustainable development is now integral to research related to tourism, social science and management, its evolution and significance at both institutional and research levels are quite recent. The first modern challenges to economic growth in terms of sustainability emerged between the 1960s and 1980s. The first studies highlighted the existence of a relationship linking the growth and availability of natural resources, focusing on the need to limit their overexploitation in order to maintain specific levels of wellbeing over time (Barnett \& Morse, 1963; Meadows et al., 1972). In the 1980s, much scientific research demonstrated the global, cumulative and, often, irreversible effects of pollution, involving all natural matrixes: air, soil, water (Hall et al., 2015). In 1987, the WCED (WCED, 1987) published the report "Our common future" (known as "Brundtland Report"), which is a milestone in the evolution of sustainability, and which provided the first (and most famous) definition of sustainable development ${ }^{\mathrm{i}}$.

In the following years, as a consequence of globalization, new challenges emerged involving social dimensions. Multinational companies began to locate their plants in developing countries; new joint ventures were constituted between companies operating in the West and developing countries, thus creating new opportunities for business and customers. The lower salaries, lower costs of land, closeness to raw materials and increased demand (UN, 2005; Navaretti et al., 2001) were some of the attractive elements. Globalization was a big opportunity, however

\footnotetext{
*Assistant Professor of Management, Sant'Anna School of Advanced Studies Pisa (battaglia@sssup.it)
} Management (symphonya.unimib.it), 3, 122-134. 
it highlighted new challenges for business and society in relation to the protection of human rights ${ }^{\mathrm{ii}}$, safeguarding local communities and local cultures, and finally integrating ethical issues in managing global supply chains (Burns, 2015; Falk, 2002; Maloni \& Brown, 2006; Salvioni \& Astori, 2013). These topics have been widely studied in the literature (Cassel, 2001; Cragg et al., 2012; Hillary, 2007; Ruggie, 2014; Seuring \& Muller, 2008). In Symphonya, Vurro et al. (2014) presented the results of some interesting research. Based on a survey involving 91 Italian companies, they demonstrated that companies implementing proactive sustainable supply chain management (SSCM) approaches, tend to increase the collaborative relations with both suppliers and distributors (and not just in one direction of the supply chain), with positive effects in terms of market performance and innovation (Vurro et al., 2014).

In addition to manufacturing businesses, since the 1990s, after the first World Conference on Sustainable Tourism (WTO, UNEP, UNESCO, EU, 1995), sustainability has also involved the tourism sector. Since then the balance between the anthropogenic burden generated by tourism and the socio-environmental issues, has become central (Buckley, 2012). Sustainability has also become an important concept in relation to tourism planning and development (Southgate \& Sharpley, 2002; Yuksel, et al., 1999), because of its both positive and negative effects on the community and society, the economy, and the natural environment. Choi and Sirakaya (2006) stressed that, if tourism development is not planned appropriately, it can destroy the very resources (e.g. economic, environmental, and social) that are the foundation of tourism in a community. Franzoni and Pellizari (2016) highlighted the importance of climate change as heavily affecting decision-making in the tourism industry. The authors describe the tourism industry as a strongly weather-sensitive economic sector, but, at the same time, they highlight the strategic importance of the challenge of climate change and global sustainability for the tourism industry.

It is evident that, to be successful, tourism development must be planned and managed in a sustainable manner. This management needs the direct and active involvement of all the subjects involved in tourism, maintaining over time the focus on protecting the local natural and cultural heritage, limiting pollution, and searching for an equilibrium between the positive and negative social, environmental and economic impacts. These subjects are all the stakeholders (Freeman, 1984) who are interested in initiatives related to tourism and who are affected by tourism flows. They can contribute actively to managing tourism related issues (Byrd, 2007). Taking into account the existing relationships is necessary in order to correctly direct decisions and to limit the risk of initiatives that do not reflect community interests and opinions. In addition, participation can potentially lead to the prevention of major conflicts between stakeholder groups (Healey, 1998), and represents an opportunity to adequately plan sustainable tourism thanks to the involvement of all public and private representatives (Battaglia et al., 2012).

Thus, the question is: who are the potential stakeholders in sustainable tourism? Firstly it is the tourists, who are the main actors and who create a positive impact and negative pressure at the local level. Their flows should be managed by both national and local authorities, which identify the potential impacts, evaluate their importance, and establish rules to limit the negative effects. Their evaluation should 
take into consideration specific features of tourism, such as the seasonality of flows and the geographical concentration of impacts. In this process authorities may be supported by (1) experts and technicians, who are capable of designing innovative programmes to make tourism sustainable, and (2) local control bodies, which are committed to monitoring the compliance of other stakeholders according to the regulations.

Another fundamental stakeholder category is the local communities and the local citizens. They enjoy the positive effects of tourism (such as income, new job opportunities) however they suffer from the environmental pressure related to pollution, waste and overexploitation of natural resources, as well as social impacts, related to an unequal distribution of wealth and risks for new forms of abuse. They can influence the initiatives of local authorities, by organizing associations specifically focused on sustainability-related topics.

Finally, businesses are key in sustainable tourism because of the strong correlation between their profitability and the preservation of the natural, historical and cultural local heritage. These features can contribute to increasing tourism attractiveness. The regenerative capacity of resources and the maintenance over time of the cultural heritage and landscape are essential to ensure the attractiveness of an area, to guarantee a high level of tourism and, finally, to support the survival and profitability of the companies located there. The challenge of sustainability for tourism companies is thus strategic, because it represents a qualifying asset of their business.

This paper is organized as follows. A brief description of the role of business is outlined in Section 2. In Section 2.1 the tourist demand is analyzed (with particular focus on outlining the profile of the sustainable tourist), and in Section 2.2, some managerial strategies that can be adopted by tourist companies are designed. In Section 3 an emerging issue is explored, related to the role of certifications in the tourism sector. Finally, in Section 4 some conclusions are drawn.

\section{The Challenge of Sustainability}

The businesses operating in the tourism sector mainly consist of SMEs, as widely stressed by the tourism literature (Thomas et al., 2011). Such organizations somehow typify the sector and can be vital to job creation (Wanhill, 1999), competitiveness (Novelli et al., 2005), economic development (Andriotis, 2002), and sustainable tourism (Fuller et al., 2005; Horobin \& Long, 1996). Because of the significant growth rates and dissemination in a specific geographical area, several papers (Holden, 2008; De Freitas, 2009; Battaglia et al., 2012) have demonstrated that tourist businesses may be considered as extremely polluting, and can generate complex social-cultural impacts. The impact of tourist flows is significant at the local level due to the cumulative effects produced by tourism businesses and the close relationship between business and other local actors. Evaluating the positive impacts and limiting the negative effects at social and environmental levels, represents the heart of sustainable tourism for businesses.

The link between this specific sector and the local natural and social contexts occurs at two levels. The reason for protecting the local natural and historicalcultural heritage is that they represent the main sources of profit for local tour 
operators. However, the possibly excessive protection and safeguarding may result unappreciated by tourists, with a negative impact on the sector.

By looking for a good balance between 'protection' and 'accessibility' is the contribution that business can make to sustainable tourism. However, finding such a balance is not the only target for a tourism business. Indeed, in defining sustainable pathways of growth, it is necessary to balance the complexity of sustainability-related issues with criteria and standards of comfort and hospitality, as well as traditional efficiency goals. Efficiently allocating natural resources (such as energy and freshwater consumption) and human resources (such as staff), is essential in order to increase the competiveness of companies, and to attract as many clients as possible through a high quality service based on a good reputation.

In summary, safeguarding the local natural and socio-cultural heritage, making it available for tourists to enjoy, guaranteeing specific levels of quality and standards and, finally, managing resources in an efficient way, represent the areas that need to be managed by tourism businesses, and represent their main challenge in relation to sustainability.

One of the problems in finding a balance amongst the various forces is the fact that only a minimal number of the negative impacts produced at social and environmental levels are generated by the provider of the service, that is the tourism business. Unlike the principal industrial sectors, in the tourism sector the impacts are primarily "indirect", that is the impacts linked to the decisions and behaviors of many different types of parties, other than business, including the very users of the service. Directing these different elements towards more sustainable behavior is one of the strategies that the most active businesses need to consider. Before outlining the tools used by businesses, it is opportune to highlight the demand side, in order to draw a profile of the sustainable tourist.

\subsection{Sustainable Tourists}

When on holiday, tourists (and in particular mass tourists) want to escape their everyday life (McKerner, 1993; Dolnicar \& Grun, 2009), and they exhibit atypical behavior compared to how they behave at home. In terms of sustainability, tourists tend to be less involved in environmentally-friendly behavior, and focus less on the social impact of their actions.

Despite this, some tourists are more inclined to sustainability (Dolnicar, 2015; Dolnicar \& Long, 2009). Tourists that are potentially of this type include visitors to parks and natural protected areas, those who spend their holidays in eco-lodges (for instance, certified facilities), excursionists, climbers, adventure tourists, vegetarians and vegans, campers, members of environmental and/or social associations/NGOs (WWF, Friends of the Earth), and [volun]tourists (tourists choosing specific destinations characterized by important social issues in order to give aid to specific communities).

The same studies have also highlighted how, in the last few years, the socialenvironmental sensitivity of tourists has increased, with an increasing appreciation of the 'socio-ecological quality' of the services provided. The research conducted to date has thus highlighted the readiness of tourists to 'appreciate' the sustainability options proposed by operators in the sector, without necessarily opting for this type of offer. A tourist operator's commitment towards sustainability, therefore, seems to 
contribute to the client's satisfaction with the service offered. However, the appreciation and commitment to sustainability occurs ex-post (or, at most, whilst the tourist is consuming the service), but it's not a determining factor in the buying choices for tourists. A 'competitive' touristic service, therefore, should offer qualitative characteristics and analogous pricing in relation to the best competitors, and, at the same time, advantages and benefits in terms of sustainability.

Considering 'sustainability' as part of 'total quality' means overcoming the idea that sustainable tourism is just a service intended for "niche markets", i.e. elite markets or those of extremely reduced dimensions. In terms of a tourism demand based on sustainability, the tourists need to go through an awareness and reinforcement phase. This needs to occur alongside the 'traditional' variables (price, comfort, location, etc), which can add a "sustainable" added value. This added value, in the same way as the other factors, can influence the tourist's choice and reward the commitment to sustainability.

In this slow and gradual maturation of the touristic demand focused on sustainability, the roles of certain entities (which can be defined as 'intermediaries') become crucial. Firstly, travel agencies and tour operators play an important role in directing their clients towards more sustainable choices. As such, there is a wide array of associations and NGOs operating in various fields of environmental protection and responsible tourism, which, although not directly advertising touristic services, are key players for the operators in the sector because they can influence the final demand.

\subsection{Managing Sustainable Business}

There are two main perspectives in relation to the management of a sustainable tourism business:

- the need for an equilibrium between the elements that characterize the sustainability strategies of a business.

- the need to establish a strategic relationship with the tourist/guest, who is the principle player (among the stakeholders involved in the management of sustainable tourism) involved in sustainability initiatives.

In order to ensure a holistic and integrated management, it may be useful to identify different types of socio-environmental impacts, and then to establish the appropriate tools to regulate and manage them. In the analysis, we consider an SME operating in one or more of the following sub-sectors: accommodation (B\&Bs, hotels, holiday residences, camping sites, holiday villages), bathhouses, restaurants and catering services, cafés and pubs, bars etc. Two types of socio-environmental impacts can be identified.

1) Direct impacts: under the direct managerial control of the organization.

2) Indirect impacts: those over which the organization has no managerial control, as they are not directly linked to the business activities.

The direct impacts include both environmental and social aspects. The direct environmental impacts include the consumption of natural resources (such as energy from non-renewable resources, freshwater), the production of unsorted waste, emissions into the atmosphere (deriving, for instance, from thermal household appliances), sound pollution, noise, odors etc. An additional category is the impacts linked to the selection of suppliers (selection of food suppliers in a 
short supply chain, organic products, etc.), which concern the sourcing policies of the business.

Besides the environmental impacts, under the direct operations of the company, the social impacts related to human resource management also need to be considered. These are connected to the protection of human rights, the definition of practices aimed at ensuring equal opportunities for the employees, health and safety, the right to education, and a transparent system of career advancement. All these direct impacts should be identified in detail by the organization, and be analyzed and evaluated. They represent the basis for the subsequent implementation of the most adequate managerial tools.

Figure 1: The Tourism Business

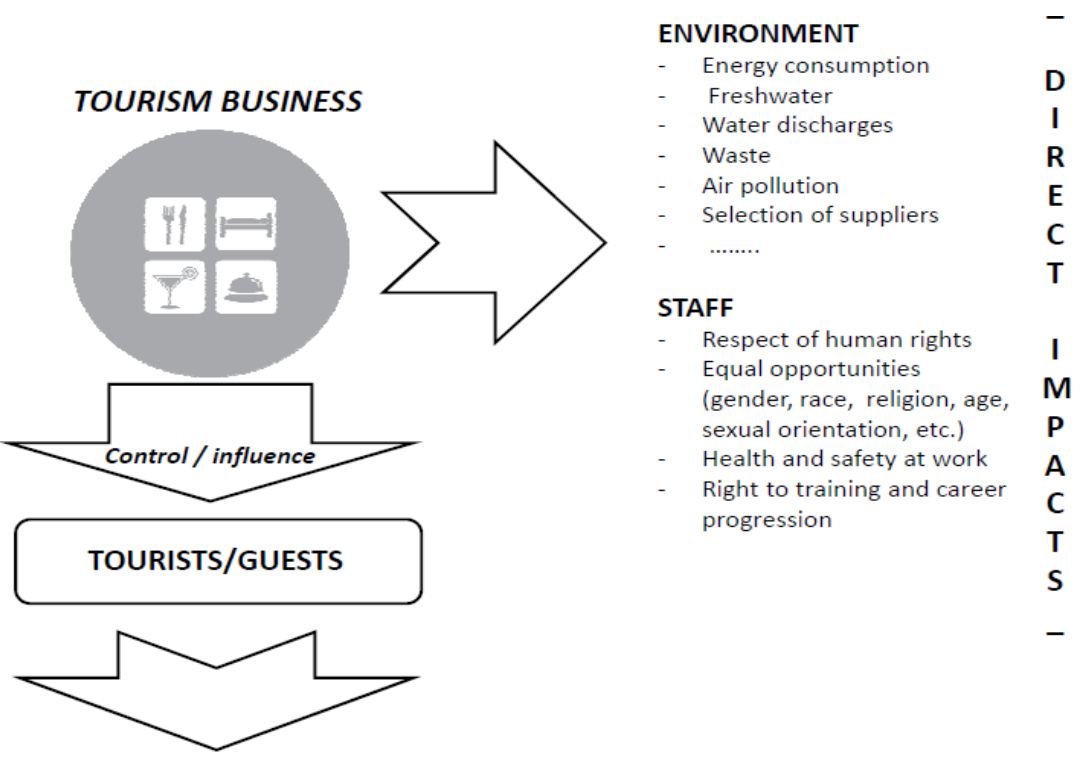

NATURAL, CULTURAL, HISTORICAL HERITAGE

[INDIRECT IMPACTS]

Indirect impacts also need to be taken into consideration. This is the most challenging area of sustainability management, as these impacts are connected with the movements and concentration of tourists in specific locations. The indirect aspects require the 'contribution' of one or more parties external to the organisation who then generate outward direct impacts (positive and/or negative, social and/or environmental). These parties can be defined as 'intermediaries', as they are located between the organisation and the final impact produced by their own behaviours. Therefore, the intermediary party directly generates a social and /or environmental impact, however its behaviour can be influenced (or even conditioned) by the choices and behaviours of the organisation. The intermediary parties, in the case of businesses such as those previously described, are the tourists (hotel guests, campers, restaurant and bar clients, etc). Their impacts can involve the environmental dimension (for instance, disrespectful behaviour towards the environment during a visit to a natural park, or the effects in terms of the sound, traffic and air pollution produced by cars), but they can also involve the socio- 
cultural sphere (for example, a lack of awareness of local customs and religious traditions of the host population, or, again, disrespect towards the socio-cultural heritage of a certain destination).

It is only through the active involvement of these parties that an indirect impact can be evaluated, managed and improved. Information and dialogue can then raise the awareness of tourists, and thus lead to a reduction in the negative impacts related to their behaviour.

Once the direct and indirect impacts have been evaluated, businesses can implement specific practices aimed at limiting the negative effects. Such practices can include both environmental and/or social dimensions, and can be directly managed on behalf of the company or go through the intermediary(-ies) or party(ies). The following box lists some of the good practices that can be adopted by businesses in the tourism sector.

Table 1: Good Practices for Sustainability - Examples

\begin{tabular}{|l|}
\hline Requesting that hotel guests use towels multiple times (and leaving them on the floor when dirty) \\
\hline $\begin{array}{l}\text { Water recovery solutions (e.g. harvest rainwater systems) and energy savings (e.g. systems for } \\
\text { automatically switching lights on and off) }\end{array}$ \\
\hline Bicycles available for guests \\
\hline Differentiated bins to stimulate garbage separation \\
\hline Solar energy systems and photovoltaic systems \\
\hline Minimal chemical cleaning products (using products with environmental certifications) \\
\hline $\begin{array}{l}\text { Technological innovative solutions (e.g. condensing boiler, household appliances in A++ class, } \\
\text { etc.) }\end{array}$ \\
\hline $\begin{array}{l}\text { Promoting green awareness initiatives to guests (regarding correct behavior when visiting specific } \\
\text { sites) }\end{array}$ \\
\hline Sustainable food products, including organic, locally-grown, vegetarian and plant-based foods \\
\hline $\begin{array}{l}\text { Excellence in employment standards to protect human rights (such as: freedom of association and } \\
\text { right to collective bargaining, elimination of forced or compulsory labour, abolition of child labour } \\
\text { and attention to underage workers, elimination of discrimination in employment and hiring, health } \\
\text { and safety at work...) }\end{array}$ \\
\hline Training and career promotion policies \\
\hline Promotion of local food \\
\hline Information on historical-cultural local heritage
\end{tabular}

\section{Certifications and Labeling}

An emerging issue in the field of sustainable tourism is the adoption and effectiveness of (eco) - certifications and labeling. These are instruments that entail an obligation to conform to a specific voluntary norm or standard of excellence established by a third party. Certifications and labeling have been used in many industries and, since the mid-1990s, they have also been adopted by the tourism sector. Although certifications and labeling are often used interchangeably, they have different meanings. Certifications are awards to businesses or activities that comply with standards that require more than what is prescribed by legal 
regulations. Standards can be product standards (related to requirements of a specific product or service), and process standards (outlining requirements that need to be respected in the development of productive processes). On the other hand, labeling is an award for an organization whose products/services have been recognized as having an excellent level of performance which can be physically measured, such as the unitary consumption of energy, water, percentage of recycled waste (Dodds \& Joppe, 2009).

Many certification and labeling schemes exist related to tourism, and in particular related to 'sustainable tourism'. These involve the measurement and monitoring of management and/or performance related to a tourism business or to subjects (local authority, agency) governing a specific tourism destination. An organization (private or public) obtaining a certificate/label can easily demonstrate its commitment towards sustainability, and can provide detailed information on how its performance has been improved.

Certification programs measure a range of environmental, socio-cultural and economic equity issues related to businesses activities, to their products/services and to the community and physical/natural context (Honey \& Rome, 2001). Many certification programs have been promoted by different organizations at an international level, and today there are more than 50 certification and labeling schemes. Programs have been created for accommodation, bathing establishments, food service providers, tour operators and intermediators, managers of protected areas, local authorities governing a specific tourism destination, etc. Some of these standards have been specifically developed for the tourism sector; others refer to organizations in general, and can be adopted by public and private organizations that manage tourism-related issues.

Compliance with the sustainability standard/performance of a specific organization is verified by a third independent body. The conformity is evaluated according to indicators and procedures established by the scheme and, if successful, the organization obtains the certificate and the right to use a specific logo. This recognition is useful to inform all external stakeholders that the organization has met the specific criteria established within the standard.

To be credible, these programs are based on third-party audits, characterized by specific check criteria and operational guidelines. The auditor should also not have any conflict of interest, and the indicators adopted should be generally recognized as representative of specific sustainability performances. Table 1 reports widely diffused sustainability certification schemes and labels. These are all schemes characterized by rigorous systems of accreditation and control.

Beyond the interest to contribute actively to sustainable development, there are several economic reasons for formalizing an environmental commitment and obtaining a certification. First, research has demonstrated that certifications are useful for teaching entrepreneurs/managers about sustainability in their operations, supporting them in the changes they need to make to their businesses (Graci \& Dodds, 2015). Certification also tends to reduce operating costs, by optimizing energy and resource use (Font et al., 2003). Certifications stimulate the continuous improvement in performance, which leads to considerable reductions of costs of utilities (water, electricity, fossil fuels), maintaining the high quality of services (Bien, 2007). 
Certifications and labels increase the knowledge of consumers and guests with regard to the commitment of business to sustainability, increasing their awareness towards responsible practices, and, finally, increasing their ability to distinguish between real sustainable practices and green washing (Graci \& Dodds, 2015). They thus increase the credibility of certified organizations, and, consequently improve their image and reputation (Bien, 2007).

Finally, certifications are an opportunity to monitor the compliance with legal requirements in the fields of environmental protection, health and safety at work, and human resource management (Chan \& Wong, 2006; Arocena \& Nuñez, 2009), thus reducing the risks of penalties and increasing trust with all stakeholders (Dodds \& Joppe, 2005).

In Italy, the Trento and Bolzano provincial authorities recently evaluated the environmental and economic impact of the adoption of the EU-Ecolabel in Trentino Alto Adige. Trentino Alto Adige has the highest number of Ecolabel certified facilities in Italy in the tourism sector (accommodation and camping). The survey was carried out between April and October 2015 and related to both certified and not certified facilities, involving more than 100 organizations. The results showed that the environmental impact of an Ecolabel facility is about $43 \%$ lower than a non-certified facility, thanks to the higher percentage of differentiated waste, the reduction in energy and freshwater consumption, and the reduction in $\mathrm{CO} 2$ emissions. In economic terms, this improved environmental performance has been quantified in a reduction of expenses of approximately $10.5 € / \mathrm{m}^{2}$ (that is $-21 \%$ in costs incurred by a non-Ecolabel structure).

Table 1: Most Important Sustainability Certification Schemes Adopted in the Tourism Industry

\begin{tabular}{|c|c|c|c|}
\hline Name & Type and nature & Brief description & $\begin{array}{l}\mathrm{No}^{\circ} \text { of Italian } \\
\text { certifications in } \\
\text { tourism * }\end{array}$ \\
\hline $\begin{array}{l}\text { Blue } \\
\text { Flag }\end{array}$ & $\begin{array}{l}\text { Destination ecolabel } \\
- \text { Private (Enacted } \\
\text { by FEE - } \\
\text { Foundation for Env. } \\
\text { Education) }\end{array}$ & $\begin{array}{l}\text { Award recognized globally aimed at beaches and marinas } \\
\text { regarding compliance with a series of stringent } \\
\text { environmental, educational, safety-related and access- } \\
\text { related criteria. Criteria refer to environmental } \\
\text { information and education, water quality, environmental } \\
\text { management, safety and availability/quality of services } \\
\text { provided to customers. }\end{array}$ & 293 beaches \\
\hline EMAS & $\begin{array}{l}\text { Process certification } \\
- \text { Public (Enacted } \\
\text { by European } \\
\text { Commission - Reg. } \\
\text { EU 1221/09) }\end{array}$ & $\begin{array}{l}\text { Premium management instrument developed by the EC } \\
\text { for companies and other organizations aimed at } \\
\text { evaluating, reporting, and improving their environmental } \\
\text { performance. EMAS establishes the requirements of an } \\
\text { Environmental Management System which has to be } \\
\text { implemented by the organization before certification. } \\
\text { Because of its public nature, it is widely diffused at the } \\
\text { EU level. }\end{array}$ & $\begin{array}{l}25 \text { (over } 1170 \\
\text { certifications in } \\
\text { Italy) }\end{array}$ \\
\hline $\begin{array}{l}\text { Green } \\
\text { Globe }\end{array}$ & $\begin{array}{l}\text { Process certification } \\
-\quad \text { Private (Green } \\
\text { Globe association) }\end{array}$ & $\begin{array}{l}\text { Sectorial certification applicable to tourism businesses } \\
\text { and involving their supply-chain. The Green Globe } \\
\text { Standard is aimed at measuring the contribution into four } \\
\text { areas of interest: Sustainable management, } \\
\text { Social/Economic performance, Cultural heritage, } \\
\text { Environmental performance, by } 44 \text { core criteria } \\
\text { supported by over } 380 \text { compliance indicators. The } \\
\text { applicable indicators vary by type of certification, } \\
\text { geographical area as well as local factors. }\end{array}$ & 4 organizations \\
\hline Travelif & Process certification & Certification system designed by the travel industry for & 9 organizations \\
\hline
\end{tabular}




\begin{tabular}{|c|c|c|c|}
\hline $\mathrm{e}$ & $\begin{array}{l}\text { - Private (Travelife } \\
\text { Ltd) }\end{array}$ & $\begin{array}{l}\text { hotels and accommodation, travel agents and tour } \\
\text { operators. It focuses on } 99 \text { sustainability criteria, and } \\
\text { provides (on the basis of environmental and social } \\
\text { performance reported) three levels of award (bronze, } \\
\text { silver and gold). The process is promoted in collaboration } \\
\text { with the EU. }\end{array}$ & (gold medal) \\
\hline $\begin{array}{c}\text { EU- } \\
\text { Ecolabe } \\
1\end{array}$ & $\begin{array}{l}\text { Product certification } \\
- \text { Public (Enacted } \\
\text { by } \quad \text { European } \\
\text { Commission - Reg. } \\
\text { EU 66/10) }\end{array}$ & $\begin{array}{l}\text { This is a voluntary label promoted by the European } \\
\text { Commission and rewarding the environmental } \\
\text { excellence of specific products and services provided by } \\
\text { businesses. In the tourism sector An eco-label can be } \\
\text { obtained by "accommodation" services (hotel, } \\
\text { farmhouses, B\&B) [requirements in the Decision } \\
2003 / 287 / \mathrm{CE} \text { ] and camp sites [requirements in the } \\
\text { Decision 2005/338/CE] }\end{array}$ & $\begin{array}{c}24 \text { camp sites } \\
\text { and } 187 \\
\text { accommodation } \\
\mathrm{s}\end{array}$ \\
\hline SA8000 & $\begin{array}{l}\text { Destination ecolabel } \\
- \text { Private (Enacted } \\
\text { by SAI - Social } \\
\text { Accountability } \\
\text { International) }\end{array}$ & $\begin{array}{l}\text { International standard aimed at providing requirements } \\
\text { based on international human rights norms and ILO } \\
\text { conventions that protect and empower all personnel. This } \\
\text { standard regards all personnel employed by the company } \\
\text { itself, as well as by its suppliers/subcontractors, sub- } \\
\text { suppliers, and home workers. }\end{array}$ & $\begin{array}{l}31 \text { organizations } \\
\text { (over } 1284 \\
\text { certifications in } \\
\text { Italy) }\end{array}$ \\
\hline
\end{tabular}

* It refers to certified organizations

\section{Conclusions}

This paper has examined the theme of sustainable tourism with a focus on the crucial elements that characterize the behavior of businesses, and which present the key challenges. Several crucial issues have emerged from our paper, both in terms of the research on sustainable tourism, and from a management perspective.

Firstly, it is only through the active participation of tourists in the improvement initiatives that tourism operators can attain the established objectives, and thus, gradually move towards sustainability. The tourist is responsible for the choice of services, and, thus, should be the first target in relation to awareness raising and increasing the demand for sustainability. Amongst all the possible stakeholders, it is the tourist's awareness that ultimately reflects the success of sustainable tourism on the end market.

The tourist needs to be able to easily identify the added value of the sustainable offer (which is never separate from the overall quality), thus contributing to reduce the 'niche' status of sustainable tourism. The success of sustainable tourism strongly depends on reconciling the needs of sustainability with the competitive capacity of the operators who commit to this cause. However, even with a more "sustainable" behavior, tourists are far from exhausting their ability to contribute to the sustainability of the sector. They need to continue to contribute with actions that are coherent with their initial choices: by saving on electricity or water and separating waste collection, choosing specific typologies of food, showing respect for the local culture and the socio-cultural heritage, etc. Education and information for tourists provided by the private operators are essential in in terms of achieving a reduction in the socio-environmental impacts.

A second decisive factor for the promotion of sustainable tourism is the close connection between touristic activities and the local context, with relationships between business and various local stakeholders. The logics of proximity do not only influence the material but also the relational sphere, thus encouraging the 
creation of local networks that extol the achievement of sustainability objectives, and that find common solutions to common problems in a certain area. Contributions to the improvement of socio-environmental plans proposed by public administrations, (for instance creating networks with other businesses in the sector, or developing projects with NGOs or local associations committed to sustainability) are some of the possible initiatives. These connections are an important feature in both promoting sustainable models of production and consumption involving the whole supply chain in the field of tourism, and preserving natural resources, as well as guaranteeing the ethical behavior of tourism entrepreneurs and guests.

The third strategic role is played by the local institutions. For example, local authorities and other intermediary institutions, such as the Chambers of Commerce, local trade associations should support local businesses in overcoming barriers (particularly costs) to implementing new strategies and instruments (such as certifications) related to sustainability. Intermediary institutions should take on the promotion of policies and instruments aimed at increasing resources. Certifications can be strategic in ensuring the commitment of tourism operators to sustainability.

In the case of certifications involving destinations, intermediary institutions can encourage the participation and contribution of businesses to locally-promoted projects. On the other hand, in the case of business certifications, institutions could offer to bear some of the costs incurred by enterprises (particularly by SMEs). In both cases, rewards for participation, aimed at creating a market differentiation between sustainable and non-sustainable businesses, should be included (Battaglia \& Frey, 2015)

To conclude, these three strategies contribute to fostering a greater culture of sustainability in tourism, creating new opportunities both for the businesses in the sector, as well as the communities facing touristic flows. Although applicable in all countries, these three strategies are key to Italy, where tradition and environmentalcultural resources represent the main attractions for tourism and where promoting sustainability, can help to guarantee a balance between the quality of service and the protection of the social and natural heritage.

\section{Bibliography}

Andriotis, K. (2002). Scale of hospitality firms and local economic development: evidence from Crete. Tourism Management, 23, 333-341.

Arocena P., Nuñez I. (2009). The effect of occupational safety legislation in preventing accidents at work: traditional versus advanced manufacturing industries. Environment and Planing $C$ : Government and Policy, 27, 159-174.

Barnett, H. and Morse C. (1963). Scarcity and Growth: The Economics of Natural Resource Availability, Baltimore: Johns Hopkins Press.

Battaglia, M, Daddi, T, Rizzi, F. (2012). Sustainable Tourism Planning and Consultation: Evidence from the Project INTER.ECO.TUR, European Planning Studies, 20 (2), 193-211

Battaglia, M., Frey, M. (2014). Public policies of promotion of CSR amongst SMEs and effects on competitiveness: the case of Tuscany region. International Journal of Business Governance and Ethics; 9 (1), $1-26$

Bien, A. (2007). A simple user's guide to certification for sustainable tourism and ecotourism, IDB Publications. 
Buckley, R. (2012). Sustainable Tourism: research and reality. Annals of Tourism Research, 39 (2), 528-546

Burns, G.L. (2015). Ethics in tourism in Hall M., Gossling S, Scott D (ed.), The Routledge Handbook of Tourism and Sustainability, New York: Routledge

Byrd, E.T. (2007). Stakeholders in Sustainable Tourism Development and their Roles: Applying Stakeholder Theory to Sustainable Tourism Development. Tourism Review, 62 (2), 6-13.

Cassel, D. (2001). Human Rights and Business Responsibilities in the Global Marketplace, Business Ethics Quarterly, 11 (2), 261-274

Chan, E. S., \& Wong, S. C. (2006). Motivations for ISO 14001 in the hotel industry. Tourism Management, 27(3), 481-492.

Choi, H.C. \& Sirakaya, E. (2006). Sustainability indicators for managing community tourism. Tourism Management, 27, 1274-1289.

Cragg, W., Arnold, D.G. \& Muchlinski, P. (2012). Guest Editors' Introduction: Human Rights and Business, Business Ethics Quarterly, 22 (1), 1-7

De Freitas, C. R. (2009). A review of "Tourism and climate change: Risks and opportunities", Journal of Sustainable Tourism, 17(5), 640-642.

Dodds, R. \& Joppe, M. (2009). Have certification programs allowed SME's in LDC's access to market? Tourism and territories journal, 1: 237-261

Dolnicar, S. (2015). Environmentally sustainable tourists? in Hall M., Gossling S, Scott D. (ed.), The Routledge Handbook of Tourism and Sustainability, New York: Routledge

Dolnicar, S. \& Grun, B. (2009). Environmentally friendly behavior - can heterogeneity among individuals and contexts/environments be harvested for improved sustainable management? Environment and behavior, 41, 693-714

Dolnicar, S. \& Long, P. (2009). Beyond Ecotourism: The Environmentally Responsible Tourist in the General Travel Experience. Tourism Analysis, 14 (4), 503-513

Falk, R. (2002). Interpreting the interaction of global markets and human rights in A. Brysk (ed.) "Globalization and human rights", Berkeley: University of California Press.

Font, X., Sanabria, R., \& Skinner, E. (2003). Sustainable tourism and ecotourism certification: raising standards and benefits, Journal of ecotourism, 2, 213-218.

Franzoni, S. \& Pellizari, C. (2016). Weather risk management in tourism industry. Symphonya. Emerging Issues in Management (symphonya.unimib.it), 1, 45-55.

http://dx.doi.org/10.4468/2016.1.05franzoni.pelizzari

Freeman, R.E. (1984). Strategic management: A stakeholder approach. Boston: Pitman.

Fuller, D., Buultjens, J., \& Cummings, E. (2005). Ecotourism and indigenous microenterprise formation in northern Australia e opportunities and constraints. Tourism Management, 26 (6), 891-904.

Graci, S., Dodds, R. (2015) Certification and labeling, in Hall M., Gossling S, Scott D (Ed.), “The Routledge Handbook of Tourism and Sustainability", New York: Routledge

Hall, M., Gossling, S., Scott D. (2015) The evolution of sustainable development and sustainable tourism, in Hall M., Gossling S, Scott D (Ed.), "The Routledge Handbook of Tourism and Sustainability", New York: Routledge

Healey, P. (1998). Collaborative planning in a stakeholder society. Town Planning Review, 69, 1-21.

Hillary, J.S. (2007) The Role of CSR in Re-empowering Local Communities, Social Responsibility Journal, 3 (2): 11 - 21

Holden, A. (2008). Environment and Tourism, Oxon: Routledge.

Honey, M \& Rome, A. (2001). Protecting paradise: certification programs for sustainable tourism and ecotourism, Washington DC: Institute for Policy Studies.

Horobin, H., \& Long, J. (1996). Sustainable tourism: the role of the small firm. International Journal of Contemporary Hospitality Management, 8 (5), 15-19.

Maloni M.J., \& Brown M.E. (2006) Corporate Social Responsibility in the Supply Chain: An Application in the Food Industry, Journal of Business Ethics, 68 (1), pp. 35-52. 
McKerner, B. (1993). Some fundamental truth about tourism: understanding tourism's social and environmental impacts. Journal of sustainable tourism, 1, 6-16.

Meadows, D.H. , Meadows, D.L., Randers, J. \& Behrens, W.W. (1972) Limits to Growth: A Report for the Club of Rome's Project on the Predicament of Mankind. New York: Universe Books

Navaretti, G.B., Falzoni, A., Turrini, A. (2001). The decision to invest in a low-wage country: evidence from Italian textiles and clothing multinationals, Journal of International Trade and Economic Development, 10 (4), 451-470.

Novelli, M., Schmitz, B., and Spencer, T. (2005). Networks, clusters and innovation in tourism: a UK experience. Tourism Management, 27: 1141-1152.

Ruggie, J.G. (2014) Global Governance and "New Governance Theory": Lessons from Business and Human Rights. Global Governance, 20 (1), 5-17.

Salvioni, D. M., Astori R. (2013). Sustainable Development and Global Responsibility in Corporate Governance, Symphonya. Emerging Issues in Management (symphonya.unimib.it), 1, 1-25. http://dx.doi.org/10.4468/2013.1.03salvioni.astori

Seuring, S, Muller M. (2008). From a literature review to a conceptual framework for sustainable supply chain management. Journal of Cleaner Production, 16 (15): 1699-1710.

Southgate, C. \& Sharpley, R. (2002). Tourism, development and the environment. In Sharpley, R. and Telfer, D.J. (eds). Tourism and development: Concepts and issues. Cleveland: Channel View Publications, 231-262.

Thomas, R., Shaw, G, Page S.J. (2011). Understanding small firms in tourism: A perspective on research trends and challenges. Tourism Management, 32(5), 963-976

UN (2005). United Nation Conference on trade and development. Strengthening participation of developing countries in dynamic and new sectors of world trade: Trends, issues and policies

Vurro C., Russo A., \& Costanzo L.A. (2014) Sustainability along the Value Chain: Collaborative Approaches and their Impact on Firm Performance. Symphonya. Emerging Issues in Management, 2, 30-44. http://dx.doi.org/10.4468/2014.2.04vurro.russo.costanzo

Wanhill, S. (1999). Small and medium tourism enterprises. Annals of Tourism Research, 27(1), 132 147.

WCED (1987). Report of the World Commission on Environment and Development: Our Common Future, United Nations Documents.

WTO, UNEP, UNESCO, EU (1995), Lanzarote Charter. Lanzarote: Proceeding of World Conference on Sustainable Tourism, April 27-28, Canary Islands, Spain.

Yuksel, F., Bramwell, B. \& Yuksel, A. (1999). Stakeholder interviews and tourism planning at Pamukkale, Turkey. Tourism Management, 20, 351- 360.

\footnotetext{
Notes

i Development that meets the needs of the present without compromising the ability of future generations to meet their own needs

ii http://www.ohchr.org/EN/Pages/Home.aspx
} 